\title{
논문 2014-09-16
}

\section{BWTS 원격 모니터링을 위한 트렌드 분석 및 진단 (Trend Analysis and Diagnosis for BWTS Remote Monitoring)}

\author{
최 욱 진, 김 진 훈, 최 휘 민, 이 광 섭, 최 우 진, 김 주 만 \\ (Wook-Jin Choi, Chin-Hoon Kim, Hwi-Min Choi, Kwang-Seob Lee, Woo-Jin Choi, Joo-Man Kim)
}

\begin{abstract}
On lot of ships, Ballast Water Treatment Systems(BWTS) are in use, or the newly built ship should be mandatory installation by 2017. It is IMO(International Maritime Organization) regulations. Because the vessel is in long distance, It is managed this system only in the vessel and it may occur considerable cost of maintenance when a problem arises from BWTS. We describe in this paper how to monitor treated ballast water to make sure the ballast water and BWTS on a ship is in proper condition, but before the port entrance. In addition, analysing and forecasting trend signal to prevent failure. Also we can expect reduce the cost of BWTS maintenance. We can monitor the sensor data value's change which collected through satellite from BWTS. And we can observate the ballasting and de-ballasting state of the vessel easily.
\end{abstract}

Keywords : BWTS, Remote monitoring, Satellite, Real-time Embedded System, SCADA system

\section{I. 서 론}

선박평형수(Ballast Water)란, 선박 운항 때 무 게중심을 유지하기 위해 배 밑바닥이나 좌우에 설 치된 탱크에 채워 넣는 바닷물을 말한다. 하지만 이 선박평형수로 인해 생태계가 피해를 받고 있다. 매 년 50억 톤 이상 이동되는 선박평형수로 7000 여종 이상의 동식물이 운반되어 해당지역의 생태계를 위 협하는 정도는 매우 심각하다. 이처럼 선박평형수는 기존의 토착 해양생태계를 파괴하는 것이 가장 큰 문제지만, 이뿐만 아니라 콜레라와 같은 전염성이 강한 병원균을 옮길 수 있어 해양환경과 사람의 건 강까지 해를 끼칠 수 있다. 이에 국제해사기구는 이 를 통제하기 위해 2004년 '선박평형수관리협약'을 채택하여 2012년 이후에 건조되는 선박은 평형수 및 침전물 내에 포함된 해양생물체나 미생물을 살 균하고 처리할 수 있는 설비인 BWTS(Ballast Water Treatment System) 즉, 선박평형수 처리시 스템을 설치해 선박평형수를 관리해야만 운항이 가

*Corresponding Author(joomkim@pnu.eu.kr) Received: 18 Feb. 2014, Revised: 21 Mar. 2014, Accepted: 4 Apr. 2014.

W.J. Choi, C.H. Kim, H.M. Choi, J.M. Kim: Busan National University

K.S. Lee, W.J. Choi: Hanla IMS c IEMEK J. Embed. Sys. Appl. 2014 June: 9(3) 127-135 ISSN : 1975-5066

http://dx.doi.org/10.14372/IEMEK.2014.9.3.127
능케 하였다[1-5]. 세계 시장 약 80조원 규모를 형 성하는 필수장비인 BWTS를 원격 모니터링 해야 하는 목적은 유지보수 비용 절감에 있다. 선박은 특 성상 국가 간의 이동이 주이기 때문에 BWTS에 문 제가 발생할 경우 전문 엔지니어 파견 및 항공편으 로 부품을 조달해야하는 문제가 발생하게 된다. 하 지만 원격 모니터링을 하게 되면 Land-Office(이 하, 육상관리국)의 전문 엔지니어가 원격으로 지시 및 통제를 할 수 있어 선박 내의 엔지니어만으로도 유지보수를 할 수 있어 시간과 비용 부담을 대폭 줄일 수 있게 된다. 본 논문이 제안하는 연구의 목 적은 단순 모니터링이 아닌, 과거의 센서 정상 동작 로깅 데이터와 비교하여 정상 범위를 벗어나는 동 작이나 변화 추세를 분석하여 이상 징후를 사전에 미리 파악하고 예측 진단을 하는 것이다.

본 논문의 구성은 다음과 같다. 피장에서는 관련 연구로서 BWTS의 구성과 원격 모니터링의 효과, BWTS 원격 모니터링 시스템을 구성하는 SCADA 시스템의 개념을 정리하고, III장에서는 BWTS 원격 모니터링 시스템 설계를 제안한다. IV장에서는 트렌 드 분석을 통한 고장예측 진단 방법을 기술하고 $\mathrm{V}$ 장에서는 제안한 방법에 대한 위한 실험 및 결과를 보인다. 마지막으로 $\mathrm{VI}$ 장에서는 본 논문의 결론을 맺는다. 


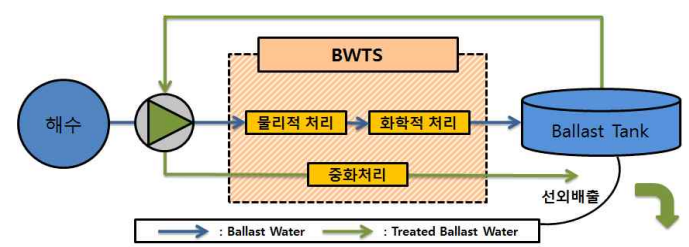

그림 1. 선박평형수 처리시스템의 기본구성

Fig. 1 Basic configuration of BWTS

표 1. 유지보수 비용

Table 1. Table of maintenance costs

\begin{tabular}{|l|l|l|l|}
\hline Cost in USD & $\begin{array}{l}\text { Local } \\
\text { expert }\end{array}$ & $\begin{array}{l}\text { Supplier } \\
\text { expert }\end{array}$ & $\begin{array}{l}\text { Remote } \\
\text { maintenance }\end{array}$ \\
\hline $\begin{array}{l}\text { Pure problem } \\
\text { solving }\end{array}$ & 1 hour & 0.5 hour & 0.5 hour \\
\hline Busy time & 5 hour & 2 days & 0.5 hour \\
\hline Expert salary & 500 & 1600 & 50 \\
\hline $\begin{array}{l}\text { Expert travel } \\
\text { expense }\end{array}$ & 0 & 2000 & 0 \\
\hline $\begin{array}{l}\text { S a t e 1 1 i t e } \\
\text { Communication } \\
\text { costs }\end{array}$ & 0 & 0 & 240 \\
\hline Total USD & 500 & 3600 & 290 \\
\hline
\end{tabular}

\section{II. 관련연구}

\section{BWTS의 구성 및 원격 모니터링의 효과}

BWTS는 선박평형수를 필터로 $50 \mu \mathrm{m}$ 이상 크기 의 생물이나 침전물을 걸러낸 후, 약품 등의 화학적 처리나 전기분해를 통해 세균의 살균처리를 하고 이 처리수를 물탱크에 주입하는 과정을 기본으로 하고 있다[6, 7]. BWTS의 기본구성은 그림 1 과 같 다.

BWTS를 원격 모니터링 하는 목적은 유지보수 비용 절감이라고 앞서 말한바 있다. 유지보수는 크 게 육상전문가, 파견전문가, 원격 유지보수 3 가지로 나뉜다. 표 1 은 각각의 경우에 소요되는 문제해결 시간과 소모비용 등을 보여준다[8].

\section{SCADA 시스템의 개념}

SCADA란 Supervisory Control And Data Acquisition의 약자로서 감시 제어 데이터 수집 시 스템을 의미한다. 원방감시제어 시스템이라고도 한 다. 원격지에 설치되어 있는 장치 및 장비를 다른 원격지에서 감시 및 제어를 하기 위해 사용되는 장 비, 시스템 및 해결방안에 대하여 광범위하게 사용 되는 용어이다. SCADA를 이용한 원격제어는 원거

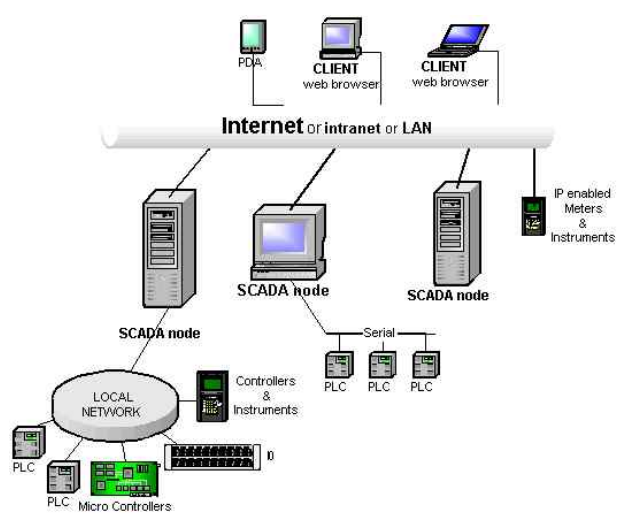

그림 2. SCADA 시스템의 기본구성[11]

Fig. 2 Basic configuration of SCADA system

리에 있는 지점에 연결된 스위치가 달린 전선과 같 이 간단한 구조로부터 중앙에 설치된 컴퓨터와 통 신을 하면서 무선, 유선, 또는 혼합 구성하여 복잡 한 통신망을 구축할 수 있다. SCADA 시스템은 자 동제어, 감시 및 정보처리 기능을 보유하여 넓은 분 야에 걸쳐 범용적으로 사용되고 있다. 수자원 관리, 송배전 업무, 가스, 원유 저장 및 공급 업무, 민방 공, 홍수경보시스템 등 수 많은 용도에 원격 감지 제어 기능을 응용함으로써 더욱 효과적이고 비용 절감 효과를 높일 수 있다[9].

$\mathrm{SCADA}$ 시스템의 1 차적인 목적은 자동화 및 원 격제어 기능의 도입을 통하여 장비와 운영 요원들 에 대한 투자 효율을 극대화시키는 것은 물론 안정 적인 통신 네트워크와 연동된 SCADA 시스템을 제 공하여 새로운 차원의 정보와 운영상의 융통성을 제공함으로써 기존 시설물의 성능을 한층 강화시키 는데 있다. 이러한 기준을 만족시키기 위하여 많은 시설 사용자가 SCADA 시스템의 구축에 눈을 돌리 고 있다. 시설물 관리의 자동화를 통하여 현장의 상 태를 파악하기 위해 기술자들이 현장 점검 서비스 에 전적으로 의존하는 것을 지양하고, 원격 감시 제 어 시스템의 도입으로 이와 같은 기술 지원을 위한 빈번한 방문이 현격히 줄어들었다. 사무실에 편안히 앉아서 혹은 멀리 떨어진 곳에서 운용 요원은 어떤 종류의 동작 상태도 감시하고 제어할 수 있다. $\mathrm{SCADA}$ 시스템은 지원이 필요한 경우 장애 내용을 알려주며, 실시간으로 경보를 발생하여 정확한 조치 를 취할 수 있도록 도와주는 각종 정보들을 제공한 다[9]. SCADA 시스템의 기본 구성은 그림 2와 같 다. 


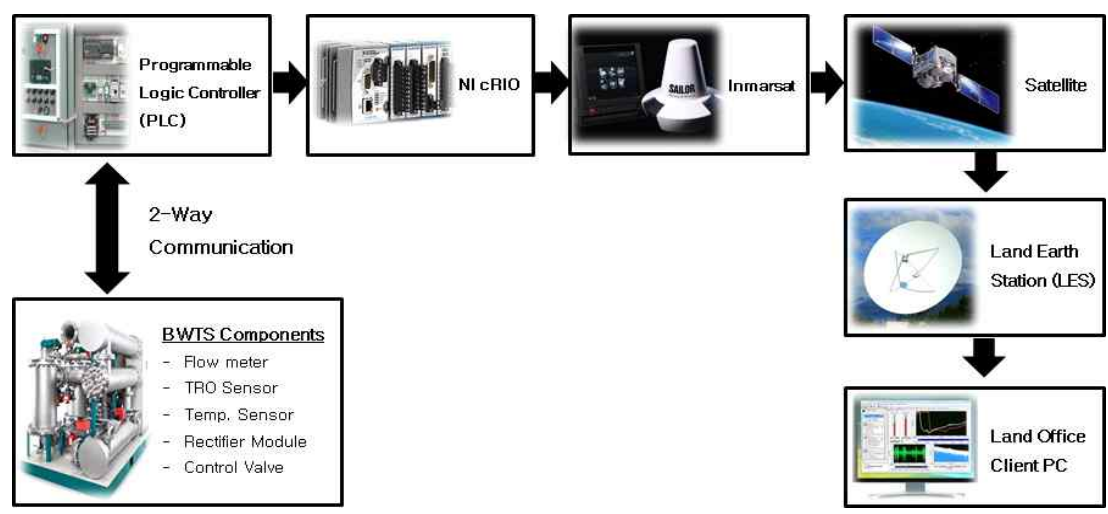

그림 3. BWTS 원격 모니터링 시스템 구성

Fig. 3 System configuration of BWTS Remote Monitoring

\section{BWTS 원격 모니터링 시스템 설계}

\section{BWTS 원격 모니터링 구성}

BWTS 원격 모니터링은 선박에 설치된 BWTS 의 각종 상태 정보를 육상의 사무실 $\mathrm{PC}$ 에서 모니 터링을 하는 것이다. 이들 사이의 통신은 인공위성 을 통해서 하며 선상과 육상관리국 간의 전체 시스 템 구성은 그림 3 과 같다.

선상에서는 BWTS에 장착된 온도, 유량, TRO, Flow meter, Rectifier Module, Control Valve 등 과 같은 수많은 센서·장비에서 수집된 데이터정보 를 PLC(Programmable Logic Controller, 프로그 램 가능 논리 제어 장치)에서 수집·분석하여 기록 관리한다. 센서 입력 및 신호처리 정보를 PLC에 장착되어 있는 터치모니터링 패널인 Proface에서 실시간으로 모니터링을 할 수 있다. 온도, 압력 등 계측 정보와 연동하여 게이지 타입이나 수치, 그래 프 등으로 디스플레이를 하여 사용자에게 직관적으 로 정보를 전달한다. 또한 센서 정보 수집 및 분석 등 정보처리 알고리즘을 구현하여 기록 및 관리한 다. RIO 장비를 통해 통신을 하고 위성장비용 메시 지 변환 알고리즘을 구현하여 INMARSAT의 선박 위성통신장비 단말기를 통해 인공위성과 연동한다. 인공위성을 거친 데이터는 육상관리국의 LES(Land Earth Station)를 거쳐 사무실의 $\mathrm{PC}$ 로 정보가 전송 되어 선주나 선박 메이커에서 모니터링을 할 수 있 게 된다[11, 12]. 육상에서는 선박으로부터 전송된 BWTS 메시지를 원시 메시지를 관리할 수 있는 통 신환경(BWTS Processing Server)을 통해 BWTS 정보를 관리할 수 있는 $\mathrm{DB}$ 에 저장하고 메시지를
호출하여 파라미터를 추출한다. 정상·비정상 알고리 즘을 적용해 유지보수 및 고장 예측 알고리즘 솔루 션을 개발 및 관리한다. LabVIEW로 디자인한 로컬 $\mathrm{PC}$ 에서 모니터링을 하고 원격지에서도 안드로이드 기반 스마트 디바이스를 통해 간단한 모니터링도 할 수 있다. 모니터링 내용은 고장 및 수명 예측, 데이터 로깅, 인디케이터 디스플레이 등이 있다.

\section{LabVIEW를 이용한 원격 모니터링}

우선, 선상에서 수집·전송된 데이터를 수신하여 LabVIEW로 모니터링 하게 되는데 Excel 데이터인 $\mathrm{Csv}$ 파일로 육상관리국 $\mathrm{PC}$ 의 일정 경로에 저장이 되고, 지정된 경로에서부터 데이터를 읽어온다. 읽 어온 데이터는 미터나 게이지, 그래프나 차트 등으 로 프론트패널에 생성한다.

변화하는 수치에 따른 상태표시가 있어야 하는 데, 특정한 값이 출력되거나 임계값을 초과하거나 못 미칠 때 텍스트 메시지나 $\mathrm{LED}$ 를 통해 알람을 표시 한다. 예를 들어, 수소 Gas를 측정하는 H2S-301 센서에서 나온 데이터 값은 0이 정상 수 치인데 만약 0 을 초과하는 값이 출력이 될 경우에 는 수소Gas가 발생하였다는 메시지와 함께 $\mathrm{LED}$ 등 이 빨간색으로 점등하여 사용자가 알 수 있게 한 다. 각각의 센서 특성에 맞게끔 비교 함수에 값을 지정하여 알림 메시지를 출력할 수 있게 하였다. 그림 4 는 이 과정의 프론트패널 화면이다.

\section{IV. 트렌드 분석을 통한 고장예측 진단}

트렌드 분석을 통해 이상 징후를 사전에 파악하 


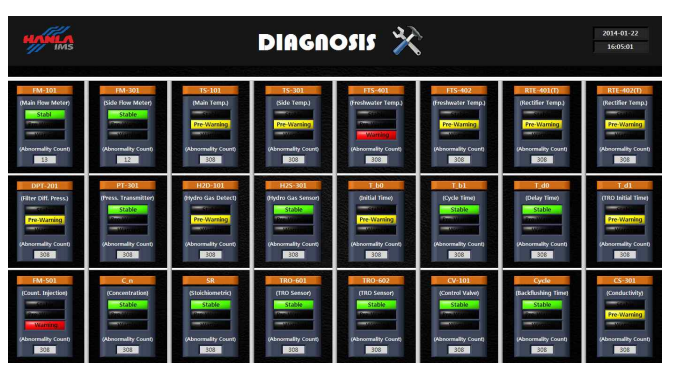

그림 4. 모니터링 프론트패널 일부

Fig. 4 Part of monitoring front panel

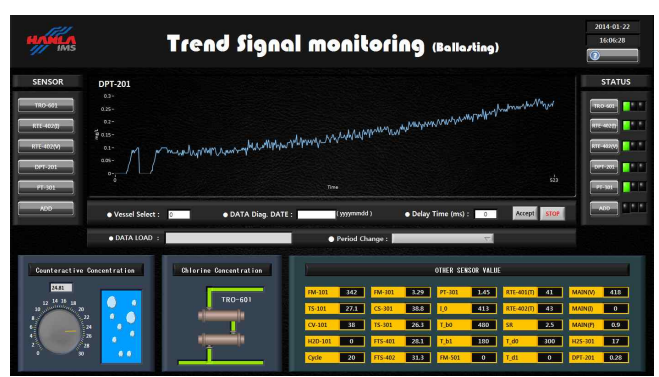

그림 5. 트렌드 모니터링 프론트패널

Fig. 5 Trend monitoring front panel

여 고장 예측 진단을 할 수 있게 하였다. 과거의 센서 정상 동작 데이터와 비교하여 정상 범위를 벗 어나는 동작이나 변화 추세를 분석하여 이상 징후 를 사전에 파악하도록 하였다. 본 절에서는 일정 값을 초과할 때 문제가 발생하는 경우와 불규칙적 인 패턴의 트렌드를 각각 분류하여 진단하는 방법 을 살펴본다.

\section{1. 트렌드 분석의 의의}

BWTS 원격 모니터링에서 트렌드를 분석해야 하는 이유는 사전에 이상 징후를 파악하여 고장을 예측 진단하기 위해서이다. 과거에 측정 및 저장되 어있는 정상 동작의 센서 데이터와 비교를 하여, 현 데이터의 정상 범위를 벗어나는 동작이나 변화 하는 추세를 분석하여 그림 5 와 같이 디스플레이 한다.

\section{2. 단순한 패턴의 트렌드 진단}

선박에 해수를 싣는 담수(湛水)과정과 반대 과 정인 배수(排水)작업을 할 때 발생되는 데이터 값 은 다양한 패턴을 갖는다. 하지만 이 각각의 센서 값은 BWTS의 특성으로 인하여 정상 수치의 데이

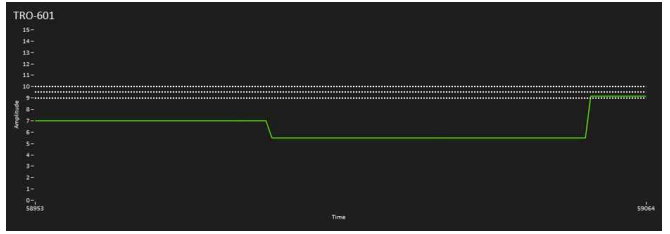

그림 6. TRO-601의 트렌드

Fig. 6 Trend of TRO-601

터 범위를 갖고 있다. 예를 들어, DPT-201이라는 센서는 필터 전·후단 압력 차이를 뜻하는데 0.2 0.6 (bar) 범위에 속할 때 정상 수치라고 할 수 있다. $0.2 \mathrm{bar}$ 미만이거나 $0.6 \mathrm{bar}$ 초과가 될 경우 경고 알림을 하여 사용자가 알 수 있게 해야 한다. 이런 센서의 고유 특성의 범위를 고려하여 $\mathrm{LabVIEW}$ 를 이용해 데이터 분석을 통한 사전 경고 및 알림 기능을 설계하도록 한다. BWTS에 장착되 어있는 센서 중에서 TRO-601은 Ballast Tank 전 단에서 $\mathrm{TRO}$ (염소산 농도)의 값을 측정하는 센서이 다. 이 센서의 특성은 측정값이 9.8 을 초과할 경우 염소산 농도의 수치가 정상 수치를 벗어난 것을 나 타낸다. 만약 트렌드 진단 중에 9.8을 넘어갈 경우 에는 이미 선상의 BWTS에서 문제가 발견된 것이 므로 고장 진단하기엔 이미 늦다. 이 경우는 선상 의 엔지니어가 실시간으로 유지보수를 했다고 가정 해야하며, 여기서는 사전진단을 해야 한다.

그림 6 에서처럼 9.0와 9.5을 임계값으로 두고 9.0 이하의 구역은 A, 9.0 9.5 사이의 구역은 B, 9.5 9.8 사이의 구역은 $\mathrm{C}$, 마지막으로 9.8 이상의 구역을 $\mathrm{D}$ 라고 잡는다. $\mathrm{A}$ 의 경우는 안정 상태이므 로 카운트하지 않고, $\mathrm{B}$ 와 $\mathrm{C}$ 의 경우를 각각 해당 구 역에 들어오는 데이터가 측정될 경우 카운트함수를 써서 각각 계산하여 위험도를 측정한다. 특히 $\mathrm{C}$ 의 경우는 $\mathrm{D}$ 로 넘어가기 전의 단계이므로 빈도수를 체 크하여 사전에 선상의 엔지니어에게 연락하여 위험 가능성을 통보하도록 한다.

그림 7은 센서 값에 대한 그래프의 임계값을 넘 어갈 때 위험도를 3 단계로 나누어 계산하는 방법을 블록다이어그램으로 나타내었다. 각각의 구역별로 임계값을 넘어갈 때 쉬프트 레지스터 함수를 이용 하여 카운트를 +1 시킨다. 이렇게 카운트된 비정상 센서 값 횟수를 데이터 총 개수로 나누어 백분율을 구한다. 백분율 값이 $0 \%$ 이상 $10 \%$ 미만일 때에는 정상 범위로서 녹색 $\mathrm{LED}$ 를 점등시켜 사용자에게 알린다. $10 \%$ 이상 $20 \%$ 미만일 경우에는 노란색 $\mathrm{LED}$ 로 경고 범위를 표시하고 $20 \%$ 이상일 경우에는 


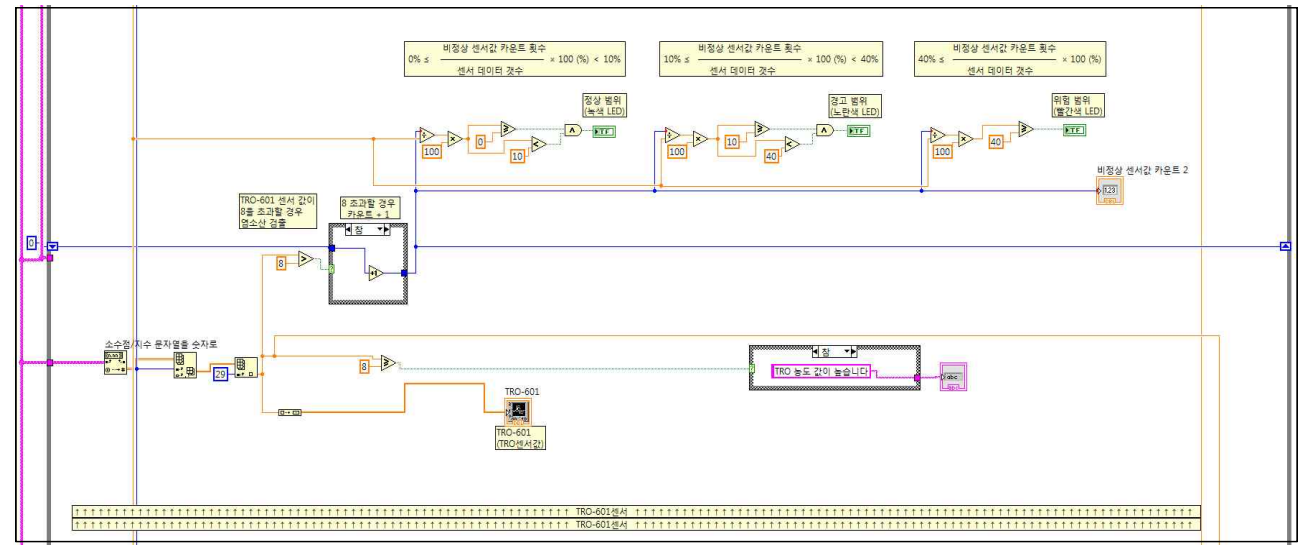

그림 7. 위험 알림 블록다이어그램 일부

Fig. 7 Part of block diagram of risk notification

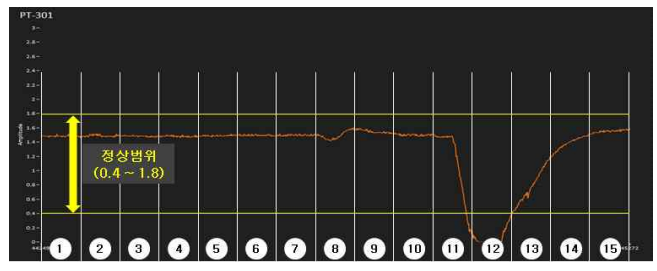

그림 8. 불규칙적인 패턴의 PT-301 트렌드

Fig. 8 Irregular pattern of PT-301 Trend

위험 범위로서 빨간색 $\mathrm{LED}$ 를 점등시켜 사용자가 트렌드 신호를 통해 동향을 분석하여 문제점 발생 징후를 파악할 수 있게 한다.

\section{3. 불규칙적인 패턴의 트렌드 진단}

센서 데이터 값이 예상하지 못하는 불규칙적인 패턴을 갖게 될 경우가 많다. 그림 8은 PT-301의 불규칙적인 패턴 트렌드이다.

PT-301은 전해조 후단의 압력을 측정하는 센 서로서 정상범위로 $0.4 \sim 1.8$ 의 값을 가지며 그 외의 범위는 전해조 후단의 압력에 이상이 있다는 것을 나타낸다. PT-301을 900초 가량의 데이터를 디스 플레이하고 이를 15 구간으로 나누었다. 11,12 구 간을 보면 정상범위를 벗어난 것을 볼 수 있다. 각 구간의 평균을 구하고 구한 평균값의 평균값과 표 준편차를 이용하여 진단을 하도록 한다.

각각의 평균값을 구하고 표준편차로 안정적인 변화율을 갖는 구간을 설정한다. 그림 9 를 보면 15 개의 평균값과 그들의 평균을 기준으로 하는 표준 편차의 구간을 볼 수 있다. 정상범위를 벗어났었던 11,12 구간이 표준편차 범위에서도 벗어나있음을
볼 수 있다.

\section{V. 실험 및 결과}

\section{1. 실험 환경 및 조건}

본 장에서는 제안한 트렌드 진단을, 실제 측정 및 기록된 데이터를 활용하여 실험에 적용하기로 한다. 데이터의 특성으로는 32 가지 종류의 센서 (FM-101, TS-101, CV-101, H2D-101, 등)가 1 초 간격으로 7398 초간 기록되었으며, 정상 범주로 기록된 데이터 1 종과 비정상 범주로 기록된 데이터 2 종으로 실험하였다. 이 실험은 실제 측정 기준을 만족하면서 다음과 같은 몇 가지 환경에서 실행되 었다.

- 비정상 데이터 시뮬레이션 및 정상 데이터 간의 비교

- 센서 특성 분석하여 변화량 없는 센서 배제, 조 건 부합하는 센서 선택 사용

- 데이터 주기와 간격은 동일

\section{2. 트렌드 알고리즘 적용}

먼저 단순한 패턴의 트렌드 진단을 정상 데이터 1 회, 비정상 데이터 2 회로 실험해 보았다. 실험에 사용된 센서 데이터는 TRO-601(Ballast Tank 전 단의 염소산 농도 측정)을 사용하였다. 그래프는 그 림 10과 같다. 표 2에서 Warning과 Pre-Hazard의 분포가 낮고 Stable이 높기 때문에 별다른 문제가 보이지 않는다. 비정상 데이터의 엑셀 파일로 실험 해 보았으며, 그래프는 그림 11 과 같다. 표 3 에서 


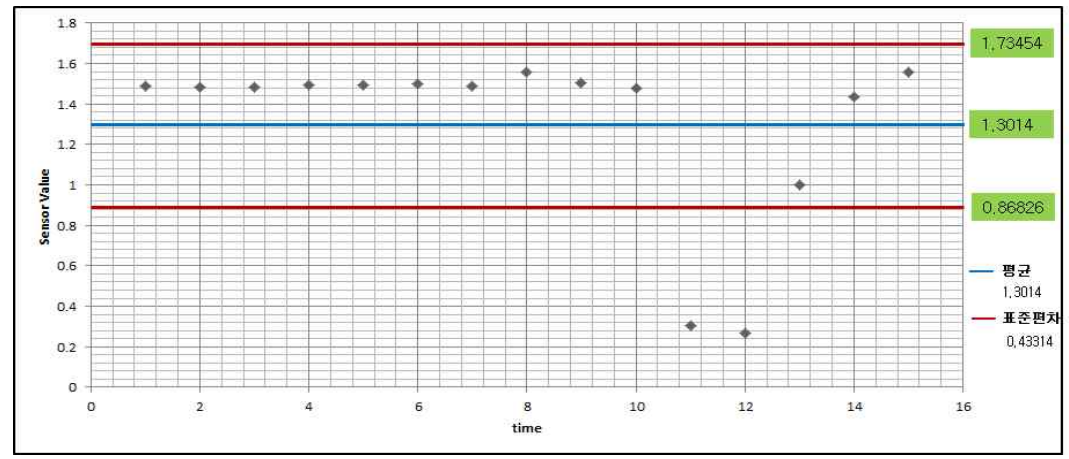

그림 9. 각 구간 평균의 평균과 표준편차의 그래프

Fig. 9 Average of each section's average and standard deviation graph

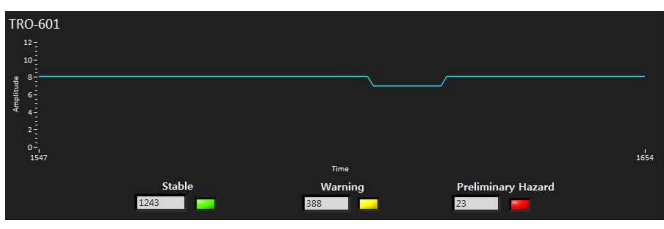

그림 10. TRO-601 (정상 데이터)

Fig. 10 TRO-601 (Normal data)

표 2. TRO-601 (정상 데이터) 구간 분포

Table 2. TRO-601 (Normal data) interval distribution

\begin{tabular}{|c|c|c|c|}
\hline Stable & Warning & $\begin{array}{c}\text { Pre- } \\
\text { Hazard }\end{array}$ & Total \\
\hline 1243 & 388 & 23 & 1654 \\
\hline $75.15 \%$ & $23.46 \%$ & $1.39 \%$ & $100 \%$ \\
\hline
\end{tabular}

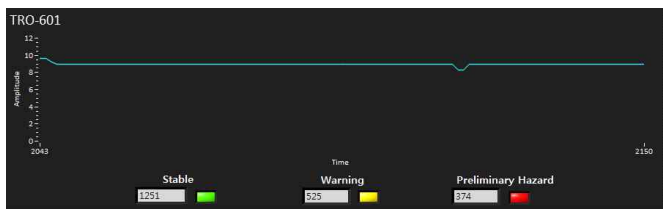

그림 11. TRO-601 (비정상 데이터_1)

Fig. 11 TRO-601 (Abnormal data_1)

표 3. TRO-601 (비정상 데이터_1) 구간 분포 Table 3. TRO-601 (Abnormal data_1) interval distribution

\begin{tabular}{|c|c|c|c|}
\hline Stable & Warning & $\begin{array}{c}\text { Pre- } \\
\text { Hazard }\end{array}$ & Total \\
\hline 1251 & 525 & 374 & 2150 \\
\hline $58.19 \%$ & $24.42 \%$ & $17.39 \%$ & $100 \%$ \\
\hline
\end{tabular}

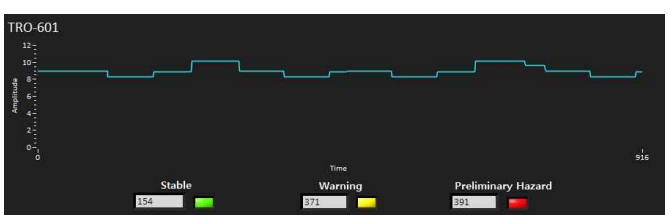

그림 12. TRO-601 (비정상 데이터_2)

Fig. 12 TRO-601 (Abnormal data_2)

표 4. TRO-601 (비정상 데이터_2) 구간 분포 Table 4. TRO-601 (Abnormal data_2) interval distribution

\begin{tabular}{|c|c|c|c|}
\hline Stable & Warning & $\begin{array}{c}\text { Pre }^{-} \\
\text {Hazard }\end{array}$ & Total \\
\hline 154 & 371 & 391 & 916 \\
\hline $16.81 \%$ & $40.50 \%$ & $42.69 \%$ & $100 \%$ \\
\hline
\end{tabular}

Warning과 Preliminary Hazard의 분포가 정상 데 이터의 경우보다 상승하였다. 예의 주시할 필요가 있다. 또 다른 비정상 데이터로 실험해보았다. 그래 프는 그림 12 와 같다. 표 4 에서 Warning과 Preliminary Hazard의 분포가 매우 높기 때문에 위험 단계로 갈 확률이 크다. 사전 통보나 지시로 조치를 취한다.

그 다음은 불규칙적인 패턴의 트렌드 진단을 위 와 마찬가지로 정상 데이터 1 회, 비정상 데이터 2 회로 실험하였다. 실험에 사용된 센서 데이터는 PT-301 (전해조 후단의 압력 측정)을 사용하였다. 그래프는 그림 13 과 같다. 그림 14 에서, 정상 데이 터의 경우 10 개 구간의 데이터 평균값이 표준편차 범위 안에 있다. 변화율이 다소 안정적임을 알 수 있다. 비정상 데이터를 이용하여 실험한 그래프는 그림 15 와 같다. 


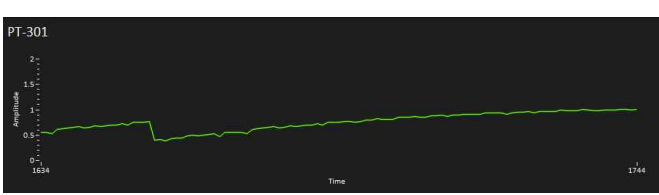

그림 13. PT-301 (정상 데이터)

Fig. 13. PT-301 (Normal data)

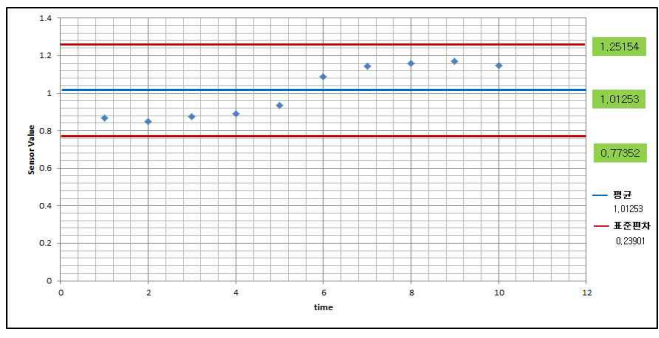

그림 14. PT-301 (정상 데이터) 구간별 평균의 평균값과 표준편차

Fig. 14 PT-301 (Normal data), Average of each interval's average and standard deviation

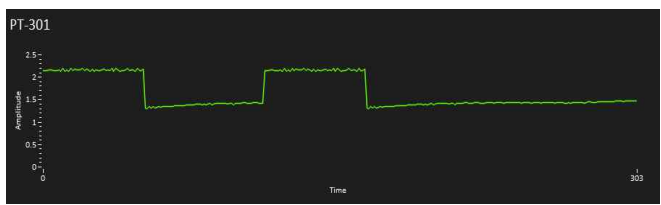

그림 15. PT-301 (비정상 데이터_1)

Fig. 15 PT-301 (Abnormal data_1)

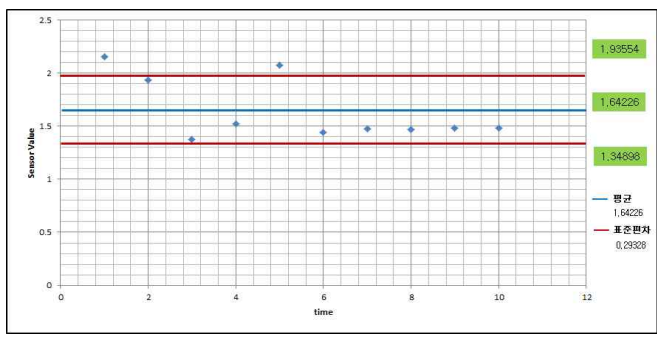

그림 16. PT-301 (비정상 데이터_1) 구간별 평균의 평균값과 표준편차

Fig. 16 PT-301 (Abnormal data_1), Average of each interval's average and standard deviation

그림 16 에서, 비정상 데이터_1의 경우 10 개 구 간 중 2 개 구간이 표준편차 범위를 벗어났다. 실제 BWTS에서 사용되는 센서 PT-301의 경우 측정치 가 $0.4 \sim 1.8$ 의 구간에 있으면 센서가 정상 동작중이

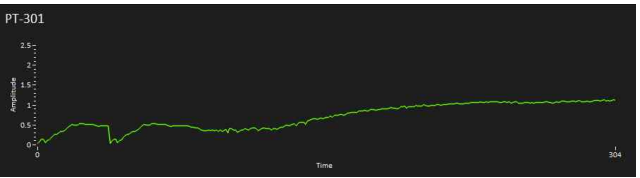

그림 17. PT-301 (비정상 데이터_2)

Fig. 17. PT-301 (Abnormal data_2)

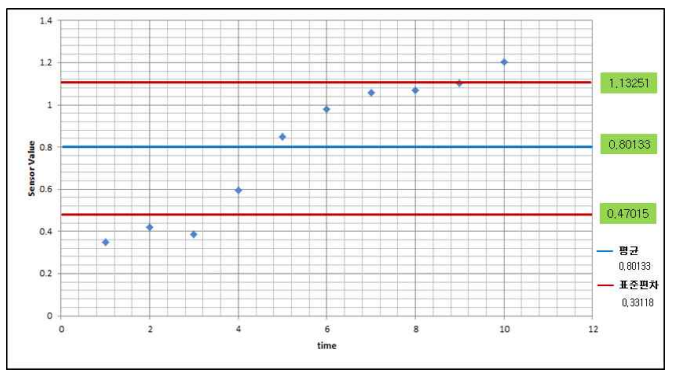

그림 18. PT-301 (비정상 데이터_2) 구간별 평균의 평균값과 표준편차

Fig. 18 PT-301 (Abnormal data_2), Average of each section's average and standard deviation

라고 간주하는데, 위의 그림에서는 정상 범위에 속 하지 않는 구간이 존재하고 패턴의 변화가 불안정 하다.

다른 비정상 데이터를 이용하여 실험한 결과 그 래프는 그림 17 과 같다. 그림 18 에서, 비정상 데이 터_2의 경우 10 개 구간 중 4 개 구간이 표준편차 범위를 벗어났다. PT-301의 정상 범위인 0.4 1.8 에 속하지 않는 구간이 존재하고 패턴의 변화가 불 안정하다.

\section{VI. 결 론}

본 논문에서는 BWTS 원격 모니터링을 위한 트 렌드 분석 및 고장 예측 진단을 제안하였다. BWTS 환경에서 각 센서 특성에 맞는 트렌드 분석 을 통해 이상 징후를 사전에 파악하여 고장 예측 진단을 할 수 있게 하였다. 과거의 센서 정상 동작 데이터와 비교하여 정상 범위를 벗어나는 동작이나 변화 추세를 분석하여 이상 징후를 사전에 파악하 도록 하였다. 이로써 원격지의 엔지니어가 분석 및 유지보수를 하여 유지보수 발생 비용을 절감할 수 있는 기대효과를 가질 수 있음을 보였다. 하지만 불규칙적인 데이터로 인한 오차가 많이 발생할 수 있기 때문에 보다 정교한 예측 알고리즘이 필요하 
며 그에 대한 연구가 진행 될 것이다.

BWTS 시장은 국제해사기구(IMO)에서 BWTS 관리 협약이 채택되어 세계적으로 약 80조원 시장 이 형성될 것이며 선박의 수많은 기자재들은 이미 원격 모니터링이 상용화 되어있지만, BWTS는 아 직 시작 단계이다. 연구 중인 과제인 BWTS 원격 모니터링은 개별적으로 동작하지만, 이는 추후 $\mathrm{SCADA}$ 시스템을 통해 선박 통합 모니터링 솔루션 으로 통합적인 원격 감시 및 제어가 될 전망이다.

\section{References}

[1] W.J. Choi, J.M. Kim, "Using LabVIEW Web Server for Ballast Water Treatment System Remote Monitoring," Proceedings of Fall Conference on IEMEK, Vol. 1, No. 1, pp.12-15, 2013 (in Korean).

[2] S. Gollasch, M. David, M. Voigt, E. Dragsund, C. Hewitt, Y. Fukuyo, "Critical review of the IMO international convention on the management of ships' ballast water and sediments," Harmful Algae, Vol. 6, pp.585-600, 2007.

[3] T.F. Sutherland, C.D. Levings, C.C. Elliott, W.W. Hesse, "Effect of a ballast water treatment system on survivorship of natural populations of marine plankton," Marine Ecol. Prog. Ser., Vol. 210, pp.139-148, 2001.

[4] http://globallast.imo.org/

[5] http://state.hi.us/dlnr/dar/ballast.html

[6] E. Tsolaki, E. Diamadopoulos, "Technologies for ballast water treatment: a review," Journal of Chemical Technology and Biotechnology, Vol. 85, No. 1, pp.19-32, 2010.

[7] M.A. Champ, "Marine Testing Board for certification of ballast water treatment technologies," Marine Pollut. Bull., Vol. 44, pp.1327-1335, 2002.

[8] G. Bakalar, V. Tomas, Z. Sesar, "Remote Monitoring of Ballast Water Treatment System Quality by Using Flow Cytometry and Satellite Communication Technologies," Proceedings of International Symposium on ELMAR, pp.259-262, 2012.

[9] A. Daneels, W. Salter, "WHAT IS SCADA?,"
Proceedings of International Conference on Accelerator and Large Experimental Physics Control Systems, 1999.

[10] http://broadwin.com/SCADA.htm

[11] B.C. Bae, H.M. Seo, I.S. Lee, Y.S. Nam, "A Consideration for a Protocol Supporting Tire Pressure Monitoring System," IEMEK J. Embed. Sys. Appl., Vol. 6, No. 6, pp.335-344, 2011 (in Korean).

[12] C.U. Kwon, K.A. Cha, J.S. Kim, "Development of a Monitoring System Based on the Cooperation of Image and Sensor Information," IEMEK J. Embed. Sys. Appl., Vol. 5, No. 2, pp.46-56, 2010 (in Korean). 


\section{저 자 소 개}

\section{최 욱 진}

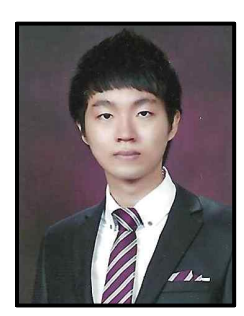

2012년, 국민대학교 전자 공학부(공학사).

2012년, 7월 2013년 2월, ETRI 모바일보안연구실 위촉연구원.

2014년 2월 현재, 부산대 학교 IT응용공학과(석사)

관심분야: 임베디드시스템, RTOS, 모바일 보안

Email:wtonic@pusan.ac.kr

\section{김 진 훈}

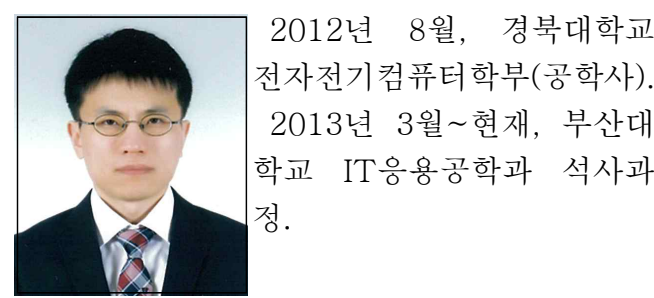

관심분야: 무선통신, 임베디드 시스템, 실시 간시스템

Email: supernova120@naver.com

\section{최 휘 민}

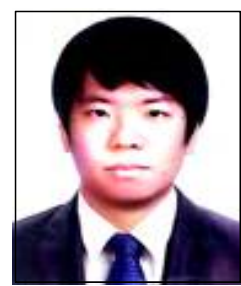

2013년 2월, 부산가톨릭 대학교 멀티미디어공학과 (공학사).

2013년 3월 현재, 부산대 학교 IT응용공학과 석사과 정.

관심분야: 모바일 컴퓨팅, RTOS, 임베디드 시스템, 통신보안, 센서네트워크

Email: pololy90@gmail.com

\section{이 광 섭}

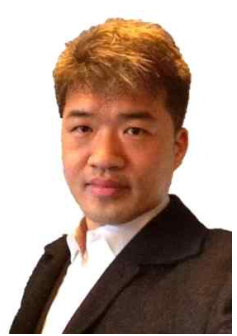

1999년 2월, 부경대학교 전자공학과(석사).

2002년 1월 2010년 7월, 금오기전 기술연구소 수석 연구원.

2010년 8월 현재, 한라 IMS 기술연구소 수석연구원. 관심분야: 임베디드시스템, 원격제어관리, 무선전력전송

Email:rhkdtjq@hanmail.net

\section{최 우 진}

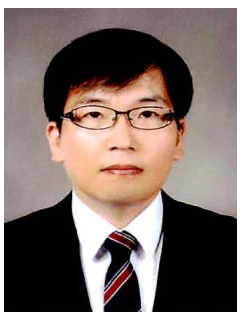

1994년 2월, 동아대학교 전기공학과(공학사).

1996년 2월, 동아대학교 전기공학과(공학석사).

2013년 8월, 동아대학교 전기공학과(공학박사).

2001년 12월 현재, 한라IMS(주) 기술연구 소장.

관심분야: 원격제어관리, 임베디드시스템

Email:research@hanlaims.com

\section{김 주 만}

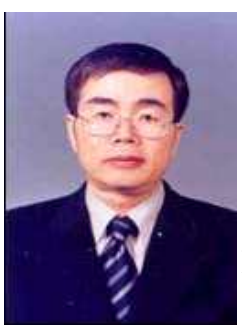

2003년, 충남대학교 컴퓨터 공학과 박사.

1985년 2000년, ETRI 책임 연구원(운영체제연구팀장).

1995년 1996년, Novell Inc. 방문연구원.

2000년 현재, 부산대 IT응용공학과 부교수. 관심분야: 임베디드 소프트웨어, Real-time OS. 분산병렬처리, 고장허용시스템

Email: joomkim@pnu.edu 